\title{
Growth and rheological changes of collenchyma cells: The fusicoccin effect
}

\author{
M. Jaccard and P. E. Pilet \\ Institute of Plant Biology and Physiology of the University, \\ Place de la Riponne 6, CH-1005 Lausanne, Switzerland
}

(Received March 7, 1978)

\begin{abstract}
Fusicoccin enhanced the growth of collocytes from Apium Graveolens petioles and modified the rheological parameters tested. But these changes do not sufficiently explain the variations of the cell wall extension. Such effects are discussed.

Key words: Cell wall - Fusicoccin - Growth - pH Effect - Rheology - Wall extension.
\end{abstract}

Fusicoccin (FC), a diterpene glucoside, promoted the elongation of various organs within minutes of application $(12,13,26)$. Such action was similar to the effect of low $\mathrm{pH}$ and auxin on cell growth. FC has been reported to increase the proton concentration in the cell wall. The similar action of $\mathrm{FC}$, low $\mathrm{pH}$, and auxin on growth $(3,4,24)$ may explain the primary action of auxin; the hypothesis presented $(7,23)$ is discussed in references $(16,27,29)$.

Collenchyma is a choice material for testing cell wall extension and rheology during growth processes $(8,9)$. The rheology (including rheological parameters and the effect low $\mathrm{pH}$ on extension rate) of isolated collocyte bundles has been shown to change during growth and differentiation of the tissues. In order to test only the interactions between growth and the rheology of the collocyte walls, we decided to use FC. This substance can stimulate growth, while biphasic auxin responses suggest that the auxin action may consist of at least two stages $(16,17,28)$. It has also been shown that the FC effect is not reduced by some inhibitors, e.g., abscisic acid $(19,2 I)$. Changes of extensibility and induced growth have been also reported for isolated collocyte bundles incubated $4 \mathrm{hr}$ in a solution containing auxin (20). But collenchyma can undergo passive growth, like the epidermis (25), being extended by the other tissues of the organs. Thus, the growth behavior of collocytes isolated from the petiole or naturally associated with it could be different. Collocyte walls prepared from intact collenchyma bundles, inside the petiole itself, were used in this study.

\section{Materials and methods}

Plants of Apium Graveolens were cultivated in a greenhouse (under controlled temperature and humidity). High- and low-growing petioles (see 9) were detached from the shoot and washed in a beaker with distilled water. After alcohol sterilization, the basal part of the petiole (9) was cut, the initial length of the collocyte 


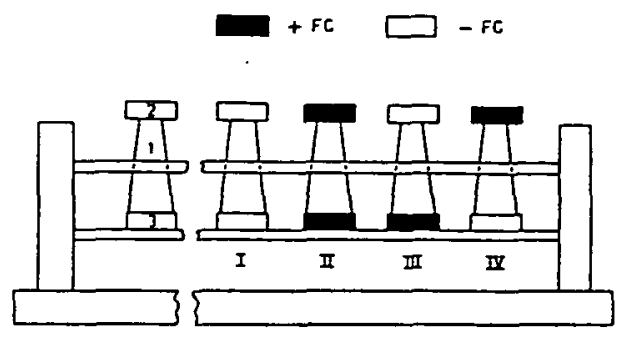

Fig. 1. Diagram showing the frame used for basal part segments and indicating several types of possible assays. 1. Basal part segment. 2. Upper agar block. 3. Lower agar block. I. Control segments. II. FC application on two segment sections. III and IV: tests analyzing effects of basipetal or acropetal FC transport in relation to collocyte growth.

bundles being $3 \mathrm{~cm} \pm 0.5 \mathrm{~mm}$. Next, high-growing petiole segments were fixed for several hours (relative humidity $100 \%$, temperature $24^{\circ} \mathrm{C}$ ) on a special frame (Fig. 1). Agar blocks ( $4 \mathrm{~mm}$ long and $10 \mathrm{~mm}$ in diameter) containing $5 \mathrm{~mm}$ phosphate buffer ( $\mathrm{pH} 6)+0.5 \%$ sucrose $\pm F C$ (at various concentrations) covered the two cut sections. This method was preferred to incubation in aqueous solution for many reasons (it was closest to the natural conditions); many types of experiments were done (Fig. 1), but only assays I and II are reported here.

After the selected incubation time, the length of the petiole segments and the collenchyma bundles was measured then the collenchyma bundles were carefully excised, quickly frozen and stored at $-20^{\circ} \mathrm{C}$. The growth of the basal part segments and the elongation of collenchyma bundles attached to them were similar. When bundles were to be used, they were thawed at room temperature and washed with phosphate buffer. Rheological parameters were measured as previously reported (8): a collocyte bundle was introduced between the pincers of a creep apparatus and submitted to a $10 \mathrm{~g}$ force applied instantaneously. The extension observed (reported to the initial length of the sample) could be separated into an instantaneous strain $\varepsilon_{1}$ and a time dependent strain $\varepsilon_{t}$ (viscoelastic extension: creep of the specimen); the sum of these two parameters giving the total strain $\varepsilon_{\text {tot. }}$ After time $\mathrm{T}$, the force applied was quickly removed and the stabilization of the residual strain $\varepsilon_{\mathrm{r}}$ caused a permanent strain $\varepsilon_{\mathrm{p}}$, which has been reported $(8)$ to be a plastic strain (having strain-hardening properties). Substraction $\varepsilon_{\mathrm{p}}$ from $\varepsilon_{\text {tot }}$ gave the elastic strain $\varepsilon_{\mathrm{el}}$. A time $\mathrm{T}$ of $2 \mathrm{~min}$ was chosen because frozen-thawed bundles (especially the FC-treated samples) showed a time-dependent strain $\varepsilon_{t}$ that stabilized after 2 min.

The extension rate of collocytes was traced with a creep apparatus and the low$\mathrm{pH}$ effects on it were calculated as previously reported (9). The extension rate at $\mathrm{pH} 6\left(\mathrm{ER}_{6}\right)$ and $\mathrm{pH} 4\left(\mathrm{ER}_{4}\right)$ were measured, then the low-pH effect on extension growth was calculated $\left(\triangle \mathrm{ER}_{4}=\mathrm{ER}_{6}-\mathrm{ER}_{4}\right)$ and expressed in logarithmic values.

\section{Results and discussion}

Fig. 2A shows the growth of the collocyte bundles treated with or without FC. Differences between $\mathrm{FC}$ treatment at $5 \times 10^{-7} \mathrm{M}$ concentration and control treatments were significant after $6 \mathrm{hr}$ of incubation. Other data (20) expressed the growth of collocytes in relation to their initial mean length in the tissues. But these data were not very sensitive because of the large variation in the initial length of the collocytes in the bundles. Thus, elongation was better expressed as a function of the initial length of the collocyte bundles. Another paper (5) has reported that when working 


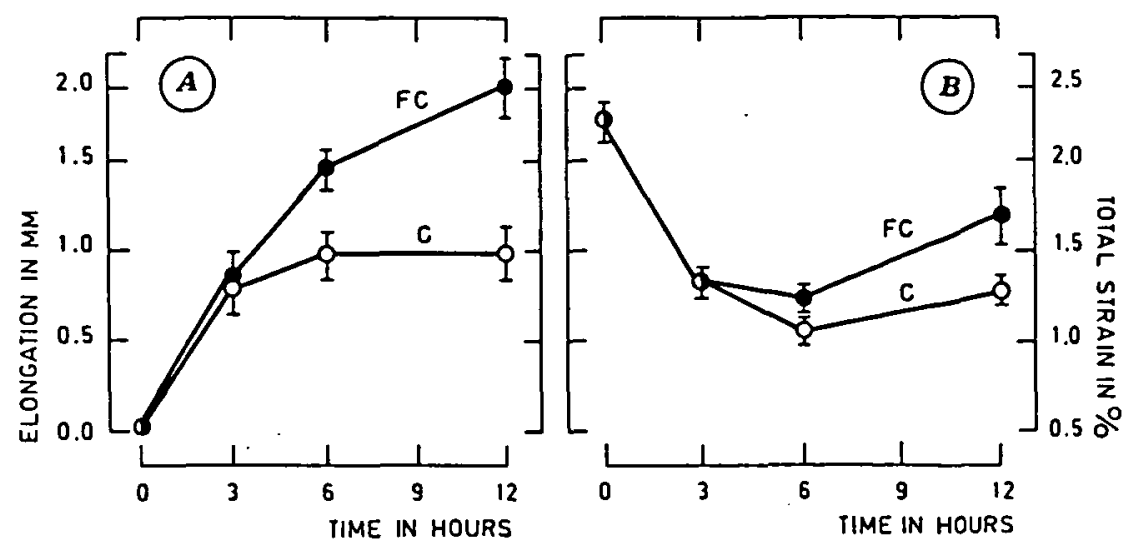

Fig. 2. Kinetic elongation and rheological parameters of collenchyma bundles treated with $(F C)$ or without $(C)$ fusicoccin $\left(5 \times 10^{-7} \mathrm{M}\right)$. A: elongation in $\mathrm{mm}$ ( \pm standard deviation). B: rheological parameter $\varepsilon_{\text {tot }}$ in $\%$ ( \pm standard deviation).

with the usual material, enhancement of the growth rate was observed some minutes after the FC application. However, the FC concentration used was higher than ours and consequently, the biological properties of the collocytes could have been different. Our selected concentration $\left(5 \times 10^{-7} \mathrm{M}\right)$ was not the optimal FC level as can be seen in Fig. 3. Also, some endogenous substances may have formed during the petiole excision to inhibit the $\mathrm{FG}$ growth effect.

The FC effect on the rheological parameter $\varepsilon_{\text {tot }}$ was not significant (Student test $\mathrm{P}=0.05$ ) before $12 \mathrm{hr}$, as can be seen in Fig. 2B. This indicates that changes of the rheology of the collocyte walls could occur after growth promotion. FC is known to have a low transport rate in organs (18); thus, the elongation observed may be limited during the first hours of treatment to the extremities of the collenchyma bundles. In creep relaxation tests, such an effect could not be detected with the ends of the collocyte samples being inserted between the pincers of a creep apparatus. However, most extensibility results of short-time experiments done with

Fig. 3. Relative elongation in $\%$ ( \pm standard deviation) of collenchyma bundles measured after $12 \mathrm{hr}$ of incubation in relation to $F C$ concentration.

$$
\Delta \mathrm{L}_{\mathrm{r}}=10^{2} \times\left(\Delta \mathrm{L}_{\mathrm{TR}}-\Delta \mathrm{L}_{\mathrm{c}}\right) / \Delta \mathrm{L}_{\mathrm{C}}
$$

$\Delta \mathrm{L}_{\mathrm{TR}}$ : elongation of collenchyma bundles treated with FC. $\Delta \mathrm{L}_{\mathrm{C}}$ : elongation of control collenchyma bundles.

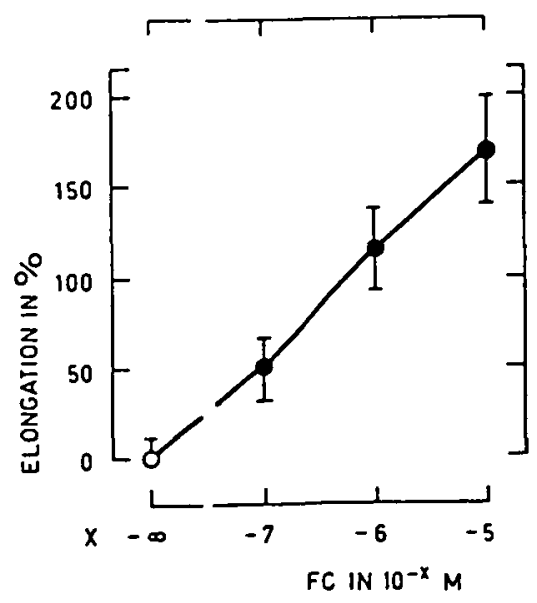


auxin have shown that extensibility changed after growth stimulation $(14,17)$; also, during the beginning of the response, the growth observed may have occurred in the ends of the segments as reported for the effect of low $\mathrm{pH}$ on extension (6).

The control tissues exhibited a stiffening of the cell walls during the kinetics of growth. It is generally assumed that this phenomenon is a result of the cell wall extension appearing without loosening, because of the strain-hardening behavior of collocytes or other primary cell walls $(2,8)$. The present data agree with this model, except that the total strain decreased during 3 to $6 \mathrm{hr}$ of the treatment, while growth did not statistically change.

Several concentrations of FC were tested and the results of the growth of collocyte bundles, after $12 \mathrm{hr}$ of incubation, are presented in Fig. 3. As can be noted, stimulation was effective from a concentration of $10^{-7} \mathrm{M}$ and increased linearly according to a logarithmic scale concentration. But growth values were not statistically different (Student test $\mathrm{P}=0.05$ ) between $10^{-6}$ and $10^{-5} \mathrm{M}$ as already reported for maize roots (19).

In contrast, from the analysis of creep tests (Fig. 4 and 5), no significant changes of the rheological parameters $\varepsilon_{\text {tot }}, \varepsilon_{t}, \varepsilon_{e l}$ and $\varepsilon_{\mathrm{p}}$ at $10^{-7} \mathrm{M}$ of $\mathrm{FC}$ were found. The parameter values presented no linear increase according to a logarithmic scale of $\mathrm{FC}$ concentration; rheological parameters indicated significant differences between concentrations of $10^{-5}$ and $10^{-6} \mathrm{M}$.

The extensibility properties of the collocyte walls, estimated by changes of the rheological parameters, do not exactly describe the in vivo modifications of the walls during the FC-induced growth. No close correlations have been found between rheological parameter data and collocyte bundle elongation. Although frozenthawed and living tissues exhibited similar rheological behavior $(8,15)$, rheological tests reduced the cross area of the samples while normal growth did not (II). On the other hand, the stress state in the creep test was not identical to that appearing during normal growth. These facts could explain the low correlation observed.

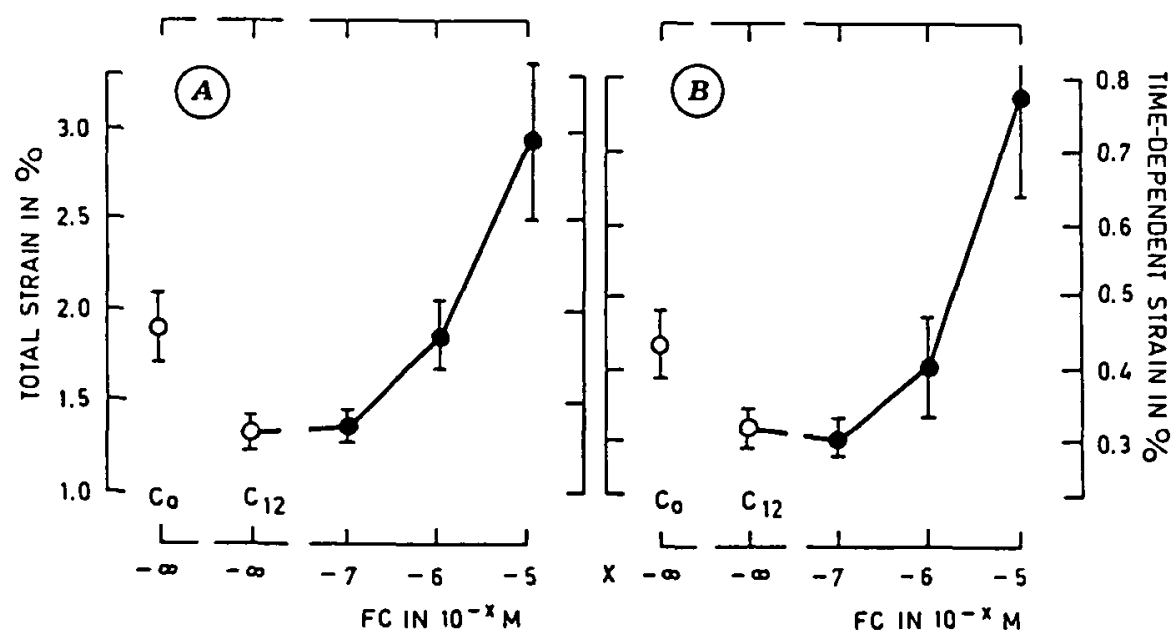

Fig. 4. Rheological parameters (in \%, 士standard deviation) of collenchyma bundles measured afler $12 \mathrm{hr}$ of incubation in relation to the $F C$ concentration tested. A: total strain $\varepsilon_{t o t}$ B: time-dependent strain $\varepsilon_{t}$. $\mathrm{C}_{0}$ and $\mathrm{C}_{12}$ : control tissues after 0 and $12 \mathrm{hr}$ of incubation, respectively. 


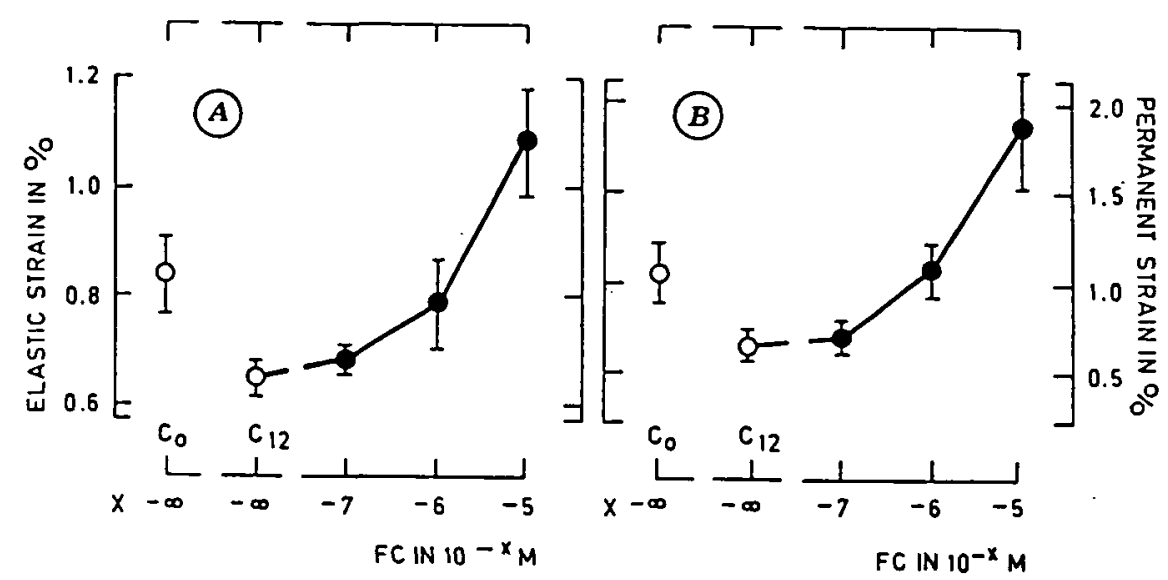

Fig. 5. Rheological parameters (in $\%$, 土standard deviation) of collenchyma bundles measured after $12 \mathrm{hr}$ of incubation in relation to the $F C$ concentration. A: elastic strain $\varepsilon_{\mathrm{el}}$. B: permanent strain $\varepsilon_{\mathrm{p}} . \mathrm{C}_{0}$ and $\mathrm{C}_{12}$ : control tissues after 0 and $12 \mathrm{hr}$ of incubation, respectively.

Total strain $\varepsilon_{\text {tot }}$ is composed of instantaneous $\varepsilon_{1}$ strain and time-dependent $\varepsilon_{\mathrm{t}}$ strain ( 8$)$; such a definition being subject to discussion ( 1$)$. In the rheological tests, the instantaneous strain $\varepsilon_{1}$ was that which appeared prior to about 2 sec. Any extension occurring after 2 sec was designated as creep and the time-dependent strain $\varepsilon_{t}$ was the measurement of a viscoelastic strain of 2 min. However, viscoelastic extension did not begin at $2 \mathrm{sec}$ and part or all of the instantaneous strain $\varepsilon_{1}$ could be a viscoelastic extension which occurred too rapidly to be estimated as creep. If this can be verified and if the FC treatment similarly affects the viscoleastic relaxation times tested, the instantaneous and time-dependent strains could show the same relative changes to FC treatment; in the present case this proposition is accepted because $\varepsilon_{\text {tot }}$ and $\varepsilon_{\mathfrak{t}}$ changed in the same relative ratio upon $\mathrm{FC}$ treatment.

These results do not exclude changes of parts of the creep curve for some relaxation times, as observed with relaxation tests on other materials treated with FC $(30)$.

Table 1 Rheological parameters and low-pH effect on the extension rate of fusicoccin-treated $(F C)$ control $\left(C_{0}\right.$, $C_{12}$ ) and low growing $(L G)$ collocytes

\begin{tabular}{lccccc}
\hline & \multicolumn{1}{c}{$\varepsilon_{\mathrm{tot}}{ }^{c}$} & \multicolumn{1}{c}{$\varepsilon_{\mathrm{el}}{ }^{c}$} & $\varepsilon_{\mathrm{p}}{ }^{c}$ & $\varepsilon_{\mathrm{t}}{ }^{c}$ & $\log 10(\Delta \mathrm{ER})^{d}$ \\
\hline $\mathrm{C}_{0}{ }^{*}$ & $18.9 \pm 2.6$ & $8.38 \pm 0.80$ & $10.3 \pm 1.88$ & $4.23 \pm 0.75$ & $2.7 \pm 0.16$ \\
$\mathrm{C}_{12}{ }^{*}$ & $13.2 \pm 1.1$ & $6.38 \pm 0.28$ & $6.34 \pm 0.9$ & $3.06 \pm 0.3$ & $2.52 \pm 0.13$ \\
$\mathrm{FC}^{a}$ & $29.6 \pm 4.6$ & $10.85 \pm 1.17$ & $18.68 \pm 3.8$ & $7.7 \pm 1.41$ & $3.13 \pm 0.09$ \\
$\mathrm{LG}^{b}$ & $9.2 \pm 1.2$ & $4.62 \pm 0.67$ & $4.50 \pm 0.60$ & $1.68 \pm 0.12$ & 0.0 \\
\hline
\end{tabular}

* See legends of Fig. 4 and 5.

FC-treated bundles (at $10^{-5} \mathrm{M}$ concentration); incubation, $12 \mathrm{hr}$.

- Low-growing collocytes (see 9 ).

c Strains expressed in \%.

d Expressed in $\% \cdot 10^{-4} \mathrm{~min}^{-1}$.

The standard deviation is given for each value. 
The permanent strain $\varepsilon_{\mathrm{p}}$ was enhanced more by FC than the elastic strain $\varepsilon_{\mathrm{el}}$; this agrees with other results $(1,2,11,14)$ which showed that the "plasticity" of the tissues increased more with increasing growth than the "elasticity".

Rheological parameters and the low-pH effect on extension rate change with growth and differentiation of collocytes (9). A close relationship may exist between rheological parameter values and the low-pH effect on extension rate values. This hypothesis was tested (Table 1). After $12 \mathrm{hr}$ of incubation, both rheological parameters and the low-pH effect on extension rate were different for control and FCtreated tissues; however, rheological parameters were significantly different between control bundles after 0 and $12 \mathrm{hr}$ of incubation, while the low-pH effect did not change. Also, collocytes of low-growing material exhibited rheological parameter values near those of control tissues after $12 \mathrm{hr}$ of incubation. In contrast, the $\mathrm{pH}$ effect on the extension rate was not significant for low-growing tissues. No close relationships were found between the low-pH effect on the extension rate and rheological parameters.

\section{Conclusion}

Extensibility and minimum relaxation time $(22,30)$ change after acidic treatment. Most results obtained have shown that FC-induced growth is a consequence of proton extrusion from the plasmalemma to the cell wall. In addition, the extensibility has been found to change when measured plasmometrically after FC treatment $(10)$.

If such a situation is the same for collocytes, this could explain the change of rheological parameters, but not the enhancement of the low-pH effect on the extension, which must be related to a possible secondary effect of fusicoccin. This hypothesis should be studied by experimentally testing the effect of auxin on rheology and the growth of collenchyma bundles.

\section{References}

(1) Cleland, R.: The mechanical behaviour of isolated Avena coleoptile walls subjected to constant stress. Properties and relation to cell elongation. Plant Physiol. 47: 805-811 (1971).

( 2) Cleland, R.: Cell wall extension. Ann. Rev. Plant Physiol. 22: 197-222 (1971).

(3) Cleland, R.: Auxin-induced hydrogen ion excretion: correlation with growth and control by external pH and water stress. Planta 127: 233-242 (1975).

(4) Cleland, R. E.: Kinetic of hormone-induced $\mathrm{H}^{+}$excretion. Plant Physiol. 58 : $210-213$ (1976).

(5) Cleland, R. E.: Fusicoccin-induced growth and hydrogen ion excretion of Avena coleoptile: relation to auxin responses. Planta 128: 201-206 (1976).

(6) Evans, M. L.: Rapid responses to plant hormones. Ann. Rev. Plant Physiol. 25: 195-223 (1974).

(7) Hager, A., H. Menzel and A. Krauss: Versuche und Hypothese zur Primärwirkung des Auxins beim Streckungwachstum. Planta 100: 47-75 (1971).

(8) Jaccard, M. and P. E. Pilet: Extensibility and rheology of collenchyma cells I. Creep relaxation and viscoelasticity of young and senescent cells. Plant $\&$ Cell Physiol. 16: 113-120 (1975).

(9) Jaccard, M. and P. E. Pilet: Extensibility and rheology of collenchyma cells II. Low pH effect on the extension of collocytes isolated from high-and low-growing material. ibid. 18: 883-891 (1977).

(10) Lado, P., F. Rasi-Caldogno and R. Colombo: Effect of cycloheximide on IAA or FC induced cell enlargement in pea internode segments. Plant Sci. Lett. 9: 93-101 (1977). 
(II) Lockhart, J. A., C. Bretz and R. Kenner: An analysis of cell wall extension. Ann. New York Acad. Sci. 144: 19-33 (1967).

(12) Marré, E., R. Colombo, P. Lado and F. Rasi-Caldogno: Correlation between proton extrusion and stimulation of cell enalrgement. Effects of fusicoccin and of cytokinins on leaf fragments and isolated cotyledons. Plant Sci. Lett. 2: 139-150 (1974).

(13) Marré, E., P. Lado, F. Rasi-Caldogno, R. Colombo and M. I. de Michelis: Evidence for the coupling of proton extrusion to $\mathrm{K}^{+}$uptake in pea internode segments treated in fusicoccin or auxin. ibid. 3: 365-379 (1974).

(14) Masuda, Y.: Auxin-induced cell expansion in relation to cell wall extensibility. Plant $\mathbb{E}$ Cell Physiol. 10: 1-9 (1969).

(15) Olson, A. C., J. Bonner and D. J. Morré: Force extension analysis of Avena coleoptile cell walls. Planta 66: 127-133 (1965).

(16) Parrish, D. J. and P. J. Davies: On the relationships between extracellular $\mathrm{pH}$ and the growth of excised pea stem segments. Plant Physiol. 59: 574-578 (1977).

(17) Penny, P., D. Penny, D. Marshall and J. K. Heyes: Early responses of excised stem segments to auxin. J. Exp. Bot. 23: 23-36 (1972).

(18) Pernet, J. J. and P. E. Pilet: in preparation

(19) Pilet, P. E.: Fusicoccin and auxin effects on root growth. Plant Sci. Lett. 7: 81-84 (1976).

(20) Pilet, P. E. and J. Cl. Roland: Growth and extensibility of collenchyma cells. ibid. 2: 203207 (1974).

(21) Pitman, M. G., N. Schaefer and R. A. Wildes: Stimulation of $\mathrm{H}^{+}$efflux and cation uptake by fusicoccin in barley roots. ibid. 4: 323-329 (1975).

(22) Rayle, D. L. and R. Cleland: Enhancement of wall loosening and elongation by acid solution. Plant Physiol. 46: 250-253 (1970).

(23) Rayle, D. L. and R. Cleland: The in vitro acid growth response: relation to in-vivo growth responses and auxin action. Planta 104: 282-296 (1972).

(24) Rayle, D. L.: Auxin induced hydrogen-ion secretion in Avena coleoptiles and its implications. ibid. 114: 63-73 (1973).

(25) Roelofsen, P. A.: Ultrastructure of the wall in growing cells and its relation to the direction of growth. Adv. Bot. Research 2: 69-149 (1965).

(26) Servettaz, O., F. Cortesi and C. P. Longo: Effect of benzyladenine on some enzymes of mitochondria and microbodies in excised sunflower cotyledons. Plant Physiol. 58: 569-572 (1976).

(27) Sakurai, N., D. J. Nevins and Y. Masuda: Auxin- and hydrogen-ion induced cell wall loosening and cell extension in Avena coleoptile segments. Plant \& Cell Physiol. 18: 371-380 (1977).

(28) Tietze-Hass, E. and K. Dörffing: Initial phases of indoleacetic acid induced growth in coleoptile segments of Avera sativa L. Planta 135: 149-154 (1977).

(29) Van der Hoef, L. N., J. S. Findley, J. J. Burke and W. E. Blizzard: Auxin has no effect on modification of external $\mathrm{pH}$ by soybean hypocotyl cells. Plant Physiol. 59: 1000-1003 (1977).

(30) Yamagata, Y. and Y. Masuda: Comparative studies on auxin and fusicoccin actions on plant growth. Plant \& Cell Physiol. 16: 41-52 (1976). 